\title{
The Duty of Care for Citizens Abroad: Security and Responsibility in the In Amenas and Fukushima Crises
}

\author{
Nina Grceger and Wrenn Yennie Lindgren \\ Norwegian Institute of International Affairs (NUPI), N-0033 Oslo, Norway \\ ng@nupi.no;wyl@nupi.no
}

Received: 13 March 2017; revised: 11 October 2017; accepted: 31 October 2017

\section{Summary}

This article analyses the state's duty of care (DoC) for citizens who fall victim to unforeseen catastrophic or violent events abroad. The DoC highlights the challenges, dynamics and relations involved in diplomatic practice that is aimed at protecting citizens outside of state borders and where traditional security concepts have little relevance. How has a globalized, more insecure world - with shifting relations and responsibilities among states, their subordinates and other carers - affected the provision of DoC? How do governments and private actors act on the DoC during and after crises? To illustrate, the article draws on the terrorist attack at a gas facility in Algeria in 2013 and the nuclear disaster in Japan in 2011, focusing particularly on the Norwegian framework and approach to protecting citizens abroad. In both crises, implementing the DoC required practical skills and measures beyond traditional diplomacy and institutionalized crisis mechanisms.

\section{Keywords}

diplomatic practice - duty of care (DoC) - security - international relations - crisis management

* Acknowledgements: This research was funded by the Research Council of Norway (RCN) programme SAMRISK II, and the research project 'Duty of Care: Protection of Citizens Abroad', 238066/H2o. The authors would like to thank the participants at a workshop in the Hague, interviewees, the editors, and two autonomous referees for valuable comments on earlier drafts.

(C) NINA GRÆGER AND WRENN YENNIE LINDGREN, 2017 | DOI 10.1163/1871191X-11302009 


\section{Introduction}

Current global work, travel and residence patterns, ${ }^{1}$ combined with a more insecure international environment, have expanded the spectre of insecurities to which citizens abroad may be exposed, whether political upheaval, violent conflicts, terror, natural disasters, or crimes conducted by individuals (including rape and abduction) or states (such as unlawful detention). Citizens may, of course, also inflict upon themselves situations where they seek assistance from their governments, for example by drug smuggling or involvement in other crimes. Furthermore, states' heightened international visibility, especially when engaged in peace-building and military operations, have made citizens abroad the targets of individuals or groups that see them as symbols of their home states' foreign policies. Even citizens of well-functioning democracies have increasingly suffered from perils, as illustrated by the terrorist attacks in European cities in recent years. Under these circumstances, there is an explicit or implicit expectation about the state's duty to care for its citizens. ${ }^{2}$

Protecting citizens beyond state borders is a matter of security. Yet existing security concepts have little relevance when analysing how citizens abroad can be protected, as well as which services they can expect states or employers to provide in crisis situations. Conceptualizations of traditional or 'hard' security focus on the survival and sovereignty of the state from external threats, including the protection of borders. Although they emphasize the security of individuals, non-traditional security concepts — such as political, societal, environmental, human and ontological security — do not specifically address security in terms of the duty held by the state towards its citizens either. ${ }^{3}$ For this purpose, this article argues that the growing insecurity and responsibilities that come with increased global interaction could be studied as part of the state's 'duty of care' (hereafter DoC). Using the DoC enables us:

1 Some 232 million people live outside their country of origin, the number of business trips and people relocating is increasing, and 1,235 million tourists travelled internationally on overnight trips in 2016; UnWTO World Tourism Barometer 2016 (Madrid: World Tourism Organization, 2016).

2 Halvard Leira, 'Beskyttelsesplikt over alle grenser?' [The Duty of Care Beyond Borders?], Norsk Statsvitenskapelig Tidsskrift, vol. 33, no. 1 (2017), pp. 78-97.

3 For early debates about security concepts, see Richard H. Ullman, 'Redefining Security', International Security, vol. 8, no. 1 (summer 1983), pp. 129-153; Jessica T. Matthews, 'Redefining Security', Foreign Affairs, vol. 68, no. 2 (1989), pp. 162-177; Nina Græger, 'Environmental Security',Journal of Peace Research, vol. 33, no. 1 (1996), pp. 109-116; Barry Buzan, Jaap de Wilde and Ole Wæver, Security: A New Framework for Analysis (Boulder, co: Lynne Rienner, 1998). For recent contributions, see Brent Steele, Ontological Security in International Relations (London: Routledge, 2008). 
[...] to capture the [above-mentioned] responsibilities and challenges in an innovative way, providing a cohesive and comprehensive framework for analysis. [...] The concept allows us to ask what kind of duty states hold toward their citizens abroad, as well as what care might imply beyond the boundary. ${ }^{4}$

The DoC covers juridical, moral and political ground. Although no generally accepted definition of the DoC exists, an element of foresight of harm, reasonable legal proximity between the parties, and a fair and reasonable interpretation of a situation should be in place to invoke the DoC. ${ }^{5}$ While the DoC is an integral part of everyday practice within medical care and health services, and increasingly also in national and international private companies, the state's duty towards the security of its citizens abroad has achieved little scholarly attention. ${ }^{6}$ In taking issue with this situation, this article addresses two questions: How has a globalized, more insecure world, where relations and responsibilities between states, their subordinates and other carers are shifting, affected the provision of the DoC? How is the DoC acted upon by governments, also in changing diplomatic practice, and by private actors when crisis occurs and after?

To illustrate the discussion, the article draws on two major incidents that affected citizens abroad: the terrorist attack at a gas facility at In Amenas, Algeria, in 2013; and the nuclear disaster in Fukushima, Japan, in 2011, following an earthquake and resulting tsunami. While these crises are different — one a planned violent action and the other because of a sudden natural disaster they are particularly illustrative of: first, how the DoC for citizens and employees abroad is increasingly invoked because of global work, residence and travel patterns; and, second, of how coordination and cooperation challenges during crises are met by embassies/foreign governments, host governments and employers who act on the DoC.

This study relies on primary sources (public documents, speeches and press releases, etc.) and secondary sources, complemented with interviews with diplomats, ministry officials, academics and central company employees (see appendix 1). Interviews provided insight into how the DoC is understood,

4 Nina Græger and Halvard Leira, The State's Duty of Care in International Relations, paper for the ISA Annual Convention, Atlanta, GA (2016), p. 2.

5 Græger and Leira, The State's Duty of Care in International Relations, p. 6.

6 Care also concerns the extension of welfare (rights) beyond the border; see Xavier Guillaume, Governing and Caring for Citizens Abroad, paper for the ISA Annual Convention, Atlanta, GA (2016). 
internalized and institutionalized (for example, crisis-response practices), particularly in the Norwegian context. ${ }^{7}$

The following section discusses how implementing the DoC forms current diplomatic practice. In subsequent sections, the Norwegian framework and approach to protecting citizens abroad will be analysed, first generally, and then through more nuanced empirical illustrations of the In Amenas and Fukushima crises. The discussion will highlight how acting on the DoC can challenge the role of foreign and host governments and employers, crisis ownership, the internal government distribution of tasks, and the lessons learned, before presenting some concluding remarks.

\section{Diplomatic Practice and the Duty of Care}

The heightened frequency of crises involving citizens abroad - whether an act of terrorism, the outbreak of violent conflict, or a devastating flood exemplify how global and trans-boundary developments are challenging diplomacy, both conceptually and in practice. ${ }^{8}$ The DoC concept arguably contributes to innovative perspectives on and empirical knowledge of practices related to diplomacy, especially during crises. In addressing globalization and global crises, traditional diplomacy - that is, where diplomats represent their states' interests 'in the sense of conveying a set of beliefs and preferences to other states' - has long revealed its limitations. ${ }^{9}$ These crises are not solved in offices or around meeting tables, but often on the ground, requiring a more 'hands on' type of diplomacy involving logistics, on-site coordination and digital communication. ${ }^{10}$

As Ole Jacob Sending, Vincent Pouliot and Iver B. Neumann argue, the effectiveness of diplomats will 'to a large degree [depend] on their ability to

7 Our primary reasons for analysing Norway are our accessibility to private and public actors involved in implementing the DoC, as well as Norway's general culture of openness.

8 See The Hague Journal of Diplomacy, vol. 10, no. 1 (2015). For example, Corneliu Bjola and Costas M. Constantinou, 'Diplomatic Challenges in a Crisis World', pp. 1-3; Costas M. Constantinou, 'In Pursuit of Crisis Diplomacy', pp. 29-34.

9 Jennifer Mitzen, 'From Representation to Governing: Diplomacy and the Constitution of International Diplomatic Power', in Ole Jacob Sending, Vincent Pouliot and Iver B. Neumann (eds.), Diplomacy and the Making of World Politics (Cambridge: Cambridge University Press, 2017), pp. 111-139, at pp. 112-113.

10 For more on the 'digital shift' in consular assistance, see Jan Melissen and Matthew Caesar-Gordon, 'Digital Diplomacy and the Securing of Nationals in a Citizen-Centric World', Global Affairs, vol. 3, no. 2 (2016). 
work with and through other actors'.11 Indeed, implementing the DoC often demands concerted efforts involving public decision-makers as well as private stakeholders. Both traditional caretakers, such as governments and their representatives, and employers, such as international enterprises, are meeting intensified demands for employee assistance. ${ }^{12}$ Although governments are responsible for the security of all citizens on their territory, including foreigners, ${ }^{13}$ more is demanded of consular services in terms of protection because of the complexity and danger in many surroundings. ${ }^{14}$ Globalization has blurred the boundaries between the inside and the outside of the state, as well as between public and private. ${ }^{15}$ Even if there is no scholarly agreement on how these processes affect the state's ability to care for its citizens abroad, the forms of governance are in a state of change. In the field of human relations, an understanding of the DoC drawing on legal duty has been developing. In the public sector, this duty covers all overseas staff employed by, or representing, the state or government.

The DoC for people working for non-governmental organizations (NGOs) and private companies, researchers, activists and journalists is in principle covered by their employers' insurance and restrictions on travel to 'high-risk' areas. ${ }^{16}$ Reliance on private security companies to protect foreign industrial and resource extraction sites abroad has become commonplace. ${ }^{17}$ The DoC is also laid down in practical measures. Prior to and during an assignment, employers should make sure that the employee is suitably prepared, trained and

11 Ole Jacob Sending, Vincent Pouliot and Iver B. Neumann, 'Introduction', in Sending, Pouliot and Neumann (eds.), Diplomacy and the Making of World Politics, p. 19.

12 NGOs and development aid actors are involved when disasters strike, but studying their DoC is beyond the scope of this article.

13 MFA, Terrorangrepet på gassproduksjonsanlegget i In Amenas: Evaluering av norske myndigheters krisehåndtering' [The Terrorist Attack on the Gas Production Plant at In Amenas: Evaluation of Norwegian Authorities' Crisis Management] (Oslo: MFA, 2014), p. 6 .

14 Halvard Leira, 'Caring and Carers: Diplomatic Personnel and the Duty of Care', The Hague Journal of Diplomacy, vol. 15, no. 2 (2018), this issue.

15 See Richard Devetak and Richard Higgott, 'Justice Unbound? Globalization, States and the Transformation of the Social Bond', International Affairs, vol. 75, no. 3 (July 1999), pp. 493498; Didier Bigo, 'Security and Immigration: Toward a Critique of the Governmentality of Unease', Alternatives, vol. 27 (2002), pp. 63-92.

16 Interview 7. See also Mateja Peter and Francesco Strazzari, 'Securitization of Research: Fieldwork under New Restrictions in Darfur and Mali', Third World Quarterly, vol. 38, no. 7 (2017), pp. 1531-1550.

17 Rita Abrahamsen and Michael Williams, Security Beyond the State: Private Security in International Politics (Cambridge: Cambridge University Press, 2011). 
equipped for, and informed about, potential risks and the dangers involved, as well as how to avoid them, or how to act if in danger. For some companies, providing immunization programmes, and assessing risks of likely illnesses or injuries during the travel or stay abroad, are also relevant. ${ }^{18}$

Implementing the DoC has become more challenging with employees and sub-contractors increasingly engaging in providing aid or other services (for example, reconstruction, security and institution-building) in post-war settings, complex emergencies, or conflict-prone areas. Furthermore, as Nina Græger and Halvard Leira argue a 'private DoC' is expected to be more centred on protecting employees as assets (for example, securing profit), whereas a 'state DoC' is likely to be centred on the same people as citizens. ${ }^{19}$ However, as noted by Lisbeth Claus, 'employers also have a moral, as well as a legal, responsibility and obligation for the health, safety, and security of their employees.' ${ }^{20}$ This distinction is, however, not black and white, as our two empirical illustrations demonstrate. For instance, when governments own shares in private companies that deploy employees to work abroad, the state has a certain duty towards them, both as citizens and employees. Moreover, a company could be partly state-owned but not have national employees, raising questions as to whether the state has a DoC towards the company's non-national employees.

There are likely to be considerable national and company variations in the understanding and implementation of the DoC vis-à-vis citizens abroad. ${ }^{21}$ The social contract and the rules and practices defining the boundaries of the political community - that is, who is entitled to care abroad — also play into this. ${ }^{22}$

\footnotetext{
18 Interview 4; and Interview 5.

19 Græger and Leira, The State's Duty of Care in International Relations.

20 Lisbeth Claus, 'Duty of Care of Employers for Protecting International Assignees, their Dependents, and International Business Travellers' (Oslo: International sos White Paper, 2009), p. 8.

21 On social benefits, see Guillaume, Governing and Caring for Citizens Abroad; on fieldwork/research, see Peter and Strazzari, 'Securitization of Research'; on variations between European and East Asian companies, see Maaike Okano-Heijmans and Matthew Caesar-Gordon, 'Protecting the Worker-Citizen Abroad: Duty of Care Beyond the State?', Global Affairs, vol. 2, no. 4 (2016), pp. 431-440.

22 See for example, Xavier Guillaume, 'Regimes of Citizenship', in Engin Isin and Peter Nyers (eds.), Routledge Handbook of Global Citizenship Studies (London: Routledge, 2014), pp. $150-158$.
} 


\section{Protecting Citizens Abroad: The Norwegian Example}

Norwegian citizens abroad are in principle well protected, and Norwegian authorities do their utmost to assist citizens in crises or accidents abroad. ${ }^{23}$ The first crisis response by the Norwegian Ministry of Foreign Affairs (MFA) is securing all Norwegian MFA (usually embassy or consulate) employees, and then other Norwegian citizens. ${ }^{24}$ There is an online self-registry system for Norwegians to use when travelling abroad. ${ }^{25}$ However, as explained by one Norwegian diplomat, this tool is not very practical (as one has to register and then unregister when departing the country) and is not actively used by most travellers. ${ }^{26}$ As a result, Norwegian embassies around the globe never really know how many Norwegians are in a country at a given time; they thus rely on 'guestimates'.27 This was particularly challenging after the December 2004 tsunami in the Indian Ocean, which revealed that the MFA's operational readiness was not dimensioned for international disasters of the tsunami's magnitude and was thus unable to protect and assist the victims on site. This situation directly instigated important domestic, bilateral and multilateral frameworks for responding to disaster and crisis, leading to the establishment of the Foreign Service Response Centre and the Government's Crisis Council in 2005. ${ }^{28}$

The Response Centre, which operates 24 hours a day, seven days a week, is part of the MFA's crisis-management mechanism in Oslo. If the crisis at hand is beyond the capacity of the MFA's crisis-response mechanism, a crisis-response team will be convened to draw on support from other Norwegian ministries (for example, the Ministries of Justice, of Transport, of Energy, of Health and of

23 Lov om utenrikstjenesten (utenrikstjenesteloven) [The Foreign Service Act], 3 May 2002; and MFA, 'Terrorangrepet på gassproduksjonsanlegget i In Amenas' [The Terrorist Attack on the Gas Production Plant at In Amenas], p. 6. MFA, 'Report to the Storting: Assistance to Norwegians Abroad', White Paper no. 12 (20102011) (Oslo: MFA, 2011).

25 See online at https://www.reiseregistrering.no/.

26 Interview 1.

27 Interview 1.

28 Interview 1. The December 2014 tsunami killed 230,000 people from fourteen countries, including 84 Norwegians; 'Flodbølgekatastrofen i Sør-Asia og sentral krisehåndtering' [The Tsunami Disaster in Southern Asia and Central Crisis Management], White Paper no. 37 (2004-2005) (Oslo: Ministry of Justice and Police, 2005). 
Defence) and also to seek independent expertise, if needed. ${ }^{29}$ Since 2005, the Norwegian MFA has convened such teams on several occasions. ${ }^{30}$

Apart from the Response Centre, several levels of responsibility are involved in crisis management when Norwegians abroad are the victims of a crisis or disaster, including the strategic crisis level in the MFA (the Director General), the Government's Crisis Council, which is the highest administrative coordination level, and the Government's Security Council — for example, if Norway deploys military forces or security personnel. The Government's Security Council is the top body and the only one to make decisions. The internal MFA's level of response - either as a crisis-management operation or an ordinary MFA operation - is usually decided upon within 30 minutes. ${ }^{31}$

Given the number of levels involved, establishing who 'owns' a crisis and thus who is responsible for implementing the DoC is rarely straightforward. According to MFA officials, defining who in government is responsible for handling different aspects of the crisis may involve tension and turf battles: 'We have fought in trenches to keep the responsibility for situations when citizens are affected by situations abroad. ${ }^{32}$ Being the lead ministry, however, does not imply extra decision-making power. All ministers remain responsible for their policy areas, and issues often fall between the areas of responsibility and attention of the ministries, blurring or complicating interaction and decision-making.

The globalization of labour markets and business engagements mean that Norwegian companies have been increasingly involved in enacting the DoC. For non-MFA employees who work for Norwegian private enterprises abroad, the employer's DoC is laid out in the Working Environment Act (2005), along with supplementary regulations. In accordance with the Act, Norwegian citizens are entitled to a physically and mentally secure work environment that has a welfare standard that is up to date with society's technological and

29 MFA, 'Report to the Storting', p. $3^{8 .}$

30 Apart from the crises described here, these include the terrorist attack in London in 2005, the Lebanon crisis in 2006, the attacks on the Norwegian Embassy in Damascus in 2006 and on Serena Hotel in Kabul in 2008, the kidnapping of a Norwegian journalist in Afghanistan in 2009, the earthquake in Chile in 2010 and the political upheaval in Egypt in 2011 (Interview 4).

31 Interview 4.

32 Interview 4. In particularly complex situations, the government may transfer overall coordination responsibility to the Ministry of Justice. 
social evolution. ${ }^{33}$ Although the Working Environment Act only applies to employees on Norwegian territory and territorial waters, Norwegian-owned companies feel a certain moral obligation to follow domestic legal obligations for national employees who are deployed to foreign countries. Large private companies usually have training and education programmes, emergency and disaster procedures, and communication routines, etc., for employees abroad, especially in precarious settings. According to a centrally-placed Statoil employee, 'the duty of care permeates everything we do in relation to risk and the protection of employees in international locations ${ }^{\prime 34}$ - and this transcends the issue of security to include health and minor accidents. Corporate ethics and social responsibilities also form the DoC. Respecting this might also have a practical side to it, related to future recruitment of personnel and the company's international standing. ${ }^{35}$ Private companies also often engage international insurance companies to help implement the DoC for their employees. For instance, the privately owned medical and travel security services firm International sos aids companies and other non-state actors with employees abroad. ${ }^{36}$

The following sections will explore two crises that are particularly illustrative of, first, how economic and political globalization is putting the security of citizens abroad at risk, because of more insecure environments and because citizens increasingly become symbols of the foreign policies of their governments; and, second, states' and other actors' efforts in implementing the DoC, highlighting issues related to preparedness, outsourcing, crisis management and the state-citizen relationship.

33 Anders Stenbrenden, 'The Responsibility of Norwegian Companies for their Employees Travelling on Business and Overseas Assignments: A Legal Perspective' (Oslo: International sos Foundation, 2016); Interview 7.

34 Interview 5.

35 The only known case law concerning employer obligations is when the Oslo District Court passed judgement in a case where the Norwegian Refugee Council was economically liable after a Canadian employee working in Kenya was kidnapped and shot (Interview 7).

36 sos International had eight customers at or close to the gas facility at In Amenas. A main task after the attack was to establish control, identify and communicate with injured persons, and identify and access logistics with a view to transporting persons and bodies out of Algeria (Interview 7). 


\section{Acting on the DoC during Crises: Two Empirical Illustrations}

The research draws on two major incidents affecting the duty of care for Norwegian citizens abroad: the terrorist attack in Algeria (2013) and the nuclear disaster in Japan (2011). The two crises share important characteristics, such as magnitude, the number and involvement of private, semi-private and government actors, distance from Norway, and the effects on future-crisis prevention measures.

In Amenas was the worst attack on Norwegian interests abroad since the Second World War and on Norwegians - five of whom were killed - since the Utøya massacre in $2011 .^{37}$ On 16 January 2013, a gas facility located 50 kilometres from the town of In Amenas in Algeria was attacked by 32 militants from the Signed in Blood Battalion, a group linked to the international terrorist network Al Qaeda. Some 800 people, 130 of whom were foreign workers representing nearly 30 different nationalities, were held hostage for three days, and 40 people were killed, some allegedly 'executed'. The scale and degree of violence led French Defence Minister Jean-Yves Le Drian to describe the militant action as an 'act of war'.38

In 2003, Statoil formed part of a joint venture consisting of three 'parent companies': Statoil; British Petroleum (BP); and Sonatrach (the Algerian stateowned partner company). Both nationals and non-nationals employed at In Amenas were hired by different companies in the consortium. Before the crisis, the joint venture seemed to guarantee its $\mathrm{DoC}$ as employer regarding a safe environment for the employees. Security at the facility was based on 'the principle of layered protection' and divided into outer security and inner security. ${ }^{39}$ Like in many other countries, foreign companies in Algeria cannot hire private security firms when national companies are part of a joint venture. Hence, Statoil and вр had to rely instead on national militaries (that is, the Algerian government) for the provision of outer security. Inner security at the facility was the responsibility of the general manager of the joint venture, a role that rotated among the three 'parent companies', because of the political sensitivity related to any non-Algerian holding security responsibility. ${ }^{40}$ In practice, inner

37 On 22 July 2013, 77 people were killed in Oslo and at Utøya island by a Norwegian extremist.

38 'Algeria Hostage Crisis: Country by Country', BBC News (25 January 2013).

39 Statoil, The In Amenas Attack: Report of the Investigation into the Terrorist Attack on In Amenas. Prepared for Statoil ASA's Board of Directors (Oslo: Statoil, 2013), p. 3.

'The In Amenas Inquests: In the Matter of the Inquests into the Deaths of [Names of Seven British Citizens are Listed]. Factual Findings' (London: Royal Courts of Justice, 26 February 2015), bullet points $28-31$. 
security was outsourced to a private subcontractor (the Algerian Facilities Management Company) managed by the joint venture, a cooperation between the Sonatrach department for internal security and the joint venture's liaison department. Specific measures included physical barriers, security and contingency plans and procedures, training, and control of access, as well as unarmed civilian guards. Statoil and other European firms nevertheless expressed concerns about operating in the Sahel region in the years prior to the attack, because of the rise of Islamic militancy, political upheavals and civil war following the 'Arab Spring..41 Although discussed, the deteriorating regional security situation from 2011 onwards did not change the alert levels or security measures at In Amenas. ${ }^{42}$

Our second illustration of how the DoC was enacted during crisis is the Fukushima Daiichi Nuclear Power Station accident in 2011, the worst nuclear energy crisis since Chernobyl in 1986. The crisis was initiated by a natural disaster consisting of a 9.0 magnitude earthquake, which came to be known as the Great East Japan Earthquake, and which struck off the north-east coast of Japan on 11 March 2011 and prompted a 10-metre-high tsunami. The tsunami damaged the nuclear power station and disabled the power supply and cooling for its three reactors, resulting in the meltdown of reactor cores and a hydrogen explosion that released radioactive material. The plant's approximately one-year-old security system (cameras and a warning system) was designed to counter hostile attempts to seize radioactive material for use in a terrorist attack, but insufficient provision had been made for the possibility of a nuclear accident occurring at the same time as a natural disaster. ${ }^{43}$

The unparalleled crisis scenario, which was later referred to as the 'triple disaster' or ' $3 / 11$ ', instilled great fear of an impending nuclear catastrophe. Coastal cities in the affected Tohoku area suffered devastating destruction from the tsunami, killing over 15,000 people and displacing 340,000 (150,000 of whom were 'nuclear refugees' from Fukushima prefecture). ${ }^{44}$ Significant

41 Iana Dreyer and Gerald Stang, Energy Moves and Power Shifts: EU Foreign Policy and Global Energy Security, report no. 18 (Paris: EU Institute for Security Studies, February 2014), pp. 43-44.

42 Statoil, The In Amenas Attack.

43 IAEA Director General, The Fukushima Daiichi Accident: Report by the Director General (Vienna: International Atomic Energy Agency, 2015).

44 Christopher Hobson, 'Human Security in Japan after the 11 March Disasters', United Nations University website (29 March 2012), available online at https://unu.edu/publications /articles/human-security-in-japan-after-the-11-march-disasters-2.html. 
infrastructure damage paralysed communication lines and complicated the response efforts of prefectural governments and embassies.

\section{Foreign and Host Government Relations during the Crises}

Acting on the DoC during crises often involves several actors, including the state hit by the crisis, states that have citizens in the area, and other actors that engage in relief or crisis management. Providing security and protection for foreign citizens as well as nationals is nevertheless the overall responsibility of the host government. While international businesses are increasingly reliant on effective host governments for security, these services are often also outsourced to sub-contractors (for example, security companies). Other states, aid agencies and NGOs can also support areas where the host government's response mechanisms are weak, thus facilitating implementation of the DoC.

As mentioned above, the Algerian government was responsible for outer security at In Amenas. Measures included a military zone in the desert area around the gas facility (the border with Libya is 78 kilometres away) protected by the Gendarmerie border guards and supported by the Algerian People's National Army if deemed necessary. ${ }^{45}$ The professional organization of the attack at In Amenas and the level of arms (including rocket-propelled grenades) indicated that it was planned in detail and over a long period. Both the media and the inquests later suggested that help from the inside was provided, which would put into question the entire security regime in Algeria and potentially also in other countries where companies must rely on national security forces for security. ${ }^{46}$

According to international law and regulations, foreign states (or their security forces) have no jurisdiction in Algeria. The Norwegian MFA 'may help private actors and host nations in providing care for their employees and in fulfilling their responsibilities', providing that the host nation so permits. ${ }^{47}$ The Norwegian government had no option but to trust the Algerian government's handling of the crisis. During the attack, a main concern was whether the Algerian authorities were able to protect, rescue and evacuate the captured Norwegian Statoil employees and, if not, how the Norwegian MFA could

45 'The In Amenas Inquests', bullet point 150.

46 'Algerian Gas Plant Siege: Military's Role Questioned', BBC News (12 September 2013); and Statoil, The In Amenas Attack.

47 Interview 5; MFA, Terrorangrepet på gassproduksjonsanlegget $i$ In Amenas [The Terrorist Attack on the Gas Production Plant at In Amenas], p. 6. 
support them in this undertaking. ${ }^{48}$ In its capacity as sovereign and as a major shareholder in Statoil, the Norwegian government apparently felt a particular duty towards the Statoil employees. ${ }^{49}$ Norwegian authorities offered assistance (for example, the Norwegian special operations forces were on stand-by at Oslo airport), but Algeria never accepted the offer. ${ }^{50}$

Apart from the obvious practical challenges on the ground, acting on the DoC was further complicated by the fact that the attack could be seen as a major humiliation for the Algerian authorities, whose inability to secure all of the citizens on their soil demonstrated a weakness of state sovereignty. Prior to the crisis, the Algerian authorities had been reluctant to communicate about Algeria's security environment, and the terrorist attack generally confirmed the lax and routine national methods of control that had worried Western oil and gas companies for some time. ${ }^{51}$ Keeping good relations with Algerian authorities was, the MFA claims, 'a challenge' that required 'the noble art of diplomacy, of bowing, and how to communicate that we have stakes in this and inform about our concerns without offending Algeria., 52

The disaster response to the triple crisis in Japan was lauded by the media as one of the speediest responses of its magnitude, with the Japanese people being recognized for their 'culture of preparedness'. However, it also revealed significant gaps in government response, especially concerning nuclear emergencies. Disaster response was an international effort, with over 160 countries and 43 international organizations participating in medical or financial support and on-the-ground relief efforts. etc. ${ }^{53}$ After the crisis, international teams worked together to coordinate communications, logistics and access

48 MFA, Terrorangrepet på gassproduksjonssanlegget i In Amenas [The Terrorist Attack on the Gas Production Plant at In Amenas], p. 24.

49 Interview 4.

50 The Algerian police authorities later accepted the help of the Norwegian Police forensic team (KRIPOs) in identifying victims (Interview 4); Sigrid E. Engebretsen-Skaret, 'Utvikling i bruken av spesialstyrkene i internasjonale operasjoner: fra enkeltmann til strategisk nivå' [Development in the Use of Special Forces in International Operations: From Individual to Strategic Level], in Tormod Heier, Anders Kjølberg and Carsten Rønnfeldt (eds.), Norge i internasjonale operasjoner. Militcermakt mellom idealer og realpolitikk [Norway in International Operations: Military Power between Ideals and Realpolitik] (Oslo: Universitetsforlaget, 2014), pp. 198-199.

$5^{1}$ Christopher Coats, 'Can Algerian Energy Buck Downward Trend With EU Help?', Forbes (20 July 2013).

52 Interview 4.

53 Jennifer D.P. Moroney, Stephanie Pezard, Laurel E. Miller, Jeffrey Engstrom and Abby Doll, Lessons from Department of Defense Disaster Relief Efforts in the Asia-Pacific Region (Santa 
capabilities, reconnaissance of the missing and medical care. The Japanese government coordinated the multi-level response with the prime minister heading an emergency-response team. The United States was especially involved through Operation Tomodachi, ${ }^{54}$ an assistance operation undertaken by the us military and the Japan Self-Defense Forces to support those affected in Tohoku. The us military also provided radiation-immune robots and unmanned aerial vehicles to assess the damage and security situation at the nuclear plant. ${ }^{55}$ Japan had prided itself on its aid-giving reputation and contributions to humanitarian assistance and was now for the first time on the receiving end of foreign assistance. The Japanese government nevertheless had issues with accepting and coordinating assistance. ${ }^{56}$ For instance, Norway's offer to provide its renowned search-and-rescue dogs (Norske Redningshunder) for locating bodies in the earthquake debris was declined by the Japanese government. ${ }^{57}$

The actions of the Japanese government and the plant operator, Tokyo Electric Power Company, were scrutinized during the hours of crisis and heavily criticized in the disaster's aftermath. ${ }^{58}$ Although efforts to increase the disaster-response capacity by leveraging comparative advantages of international allies and regional partners were undertaken, in reality such collaboration often resulted in disorganization and insufficient information-sharing, which in turn led to frustration and mistrust. ${ }^{59}$ The parallel yet largely different responses of the Japanese government and other governments (particularly the United States but also Norway), and evaluations of the seriousness of the nuclear meltdown and radiation effects, led to competing conclusions

Monica, CA: RAND Corporation, 2013). http://www.rand.org/pubs/research_reports/RR 146.html.

54 The use of the word Tomodachi (a Japanese word for 'friend') reflected the close alliance partnership. Operation Tomodachi lasted from 11 March-8 April 2011.

Richard J. Samuels, 3.11: Disaster and Change in Japan (Ithaca, NY: Cornell University Press, 2013), p. 20.

$5^{6}$ The Official Report of the Fukushima Nuclear Accident Independent Investigation Commission (Tokyo: National Diet of Japan, 2012).

57 Interview 4.

$5^{8}$ The Official Report of the Fukushima Nuclear Accident Independent Investigation Commission; Independent Investigation Commission on the Fukushima Nuclear Accident, The Fukushima Daiichi Nuclear Power Plant Station Disaster: Investigating the Myth and Reality (New York, NY: Routledge, 2014); and Kyle Cleveland, 'A Good Plan Undone: The Politics of Crisis Management in the Fukushima 3.11 Disasters', Etnografia e Ricerca Qualitativa (February 2015), pp. 217-234. 
regarding response to and communication of the crisis, and most notably on where to establish evacuation zones in Fukushima. ${ }^{60}$

Officially, the Japanese government is responsible for making decisions related to the security of foreign as well as Japanese citizens. Although the demarcation between host country and embassy roles was contested, Norwegian decisions about what to do were based primarily on the Japanese government's assessment of the situation. Fearing that the Japanese authorities could face difficulty in protecting Norwegians, the Norwegian MFA consulted independent resources, such as the Norwegian Radiation Protection Authority (Statens Strålevern) and academics, when making decisions about the radiation risk level. ${ }^{61}$ As a precautionary measure, the Norwegian Embassy evacuated to Kobe (525 kilometres south-west of Tokyo) and worked from there for two weeks. The MFA's travel advisory (Reiseråd) advised Norwegian citizens to evacuate Japan and the Norwegian Embassy arranged for a Norwegian plane to collect Norwegians (and others once the Norwegian demand was met) for a token charge of 5,000 NOK. ${ }^{62}$

The actions of close allies and partners who have citizens in a crisis area sometimes affect the national resources made available to act on the DoC. ${ }^{63}$ During the Fukushima crisis, for example, the Norwegian media reported that some governments (such as the Swedish and British) shipped iodine tablets to Tokyo, whereas Norway did not. Media speculations about certain governments knowing more than others eventually resulted in a cohesive policy line on iodine provisions. ${ }^{64}$ Similarly, the presence of high-level individuals in a crisis area may encourage heightened government response. At In Amenas, for instance, the Norwegian minister for development was the stepfather of one of the gas facility employees, and in Fukushima, a high-profile Norwegian politician's son, who was studying in the region, was unaccounted for a couple of days. ${ }^{65}$

\footnotetext{
$60 \quad$ Interview 2; Interview 3; and Interview 6.

61 Interview 1.

62 Interview 4.

63 Interview 1; and Interview 4.

64 Interview 4.

65 Interview 1; and Interview 4.
} 


\section{Whose Duty, Whose Crisis? Tasks and Turf Battles}

During crises, the coordination of assistance on site and in the victims' home countries is demanding, making the division of responsibilities in fulfilling the DoC even more important. ${ }^{66}$

Although the attack at In Amenas was not a crisis involving 'classic' national interests, it was a major attack against Norwegian citizens and interests: thirteen of the seventeen Statoil employees were Norwegian and the Norwegian government owns 67 per cent of Statoil. Establishing ownership of the crisis was, however, not straightforward, creating a grey zone dividing the private actors (the joint venture and individual oil companies, Statoil and BP), the home governments and the Algerian government (which also owned Sonatrach). According to the Norwegian MFA, 'this made In Amenas the perfect case of showing competence, or lack of such, in handling crises abroad'. ${ }^{67}$ Furthermore, as noted above, more complex business ownership structures, and the fact that both private actors and states may own shares in an international company, also highlighted the private-public dimension of the DoC. As emphasized by the MFA, 'Remember that Statoil is no longer Norwegian; nor is Yara or Telenor. What are the borders of Norwegian interests? Norwegian is not Norwegian anymore. 68

The Norwegian MFA and the Response Centre played an important role in implementing the DoC during the siege at In Amenas. A crisis team was convened to assess the situation and establish what kind of national resources and competences were needed. Statoil sent a liaison to the MFA, and vice versa, who acted as the eyes and ears of the host organization. ${ }^{69}$ The Response Centre facilitated response for Statoil, including the transportation of people (and later, coffins) back to Norway. The MFA also sent an emergency unit consisting of employees, police, special operations forces and health personnel to Algeria to support the Norwegian Embassy in Algiers. Having a representative from the Norwegian special operations forces ensured access to information from Algerian military authorities and local security forces. ${ }^{70}$

In interviews, Norwegian MFA representatives stressed that they had never considered seizing national responsibility during the In Amenas crisis, since

\footnotetext{
66 Græger and Leira, The State's Duty of Care in International Relations.

67 Interview 4.

68 Interview 4.

69 Interview 4.

70 Engebretsen-Skaret, 'Utvikling i bruken av spesialstyrkene i internasjonale operasjoner' [Development in the Use of Special Forces in International Operations], p. 198.
} 
the MFA had confidence that Statoil had substantial crisis-management infrastructure. Still, there was close contact and continuous dialogue at the top level during the occupation of the facility, involving Statoil's company management in Stavanger in Norway, the Algerian government, and the Norwegian government at ministerial and diplomatic levels. ${ }^{71}$ The Norwegian government also received highly classified information on Algeria from NATO allies during the crisis. Drawing on experience from the attack on Serena Hotel in Kabul, Afghanistan, in January 2008, where the Norwegian foreign minister, diplomats and journalists were present and one Norwegian journalist was killed, the Norwegian MFA decided that 'to sit on that info without sharing it with Statoil could be fatal. ${ }^{72}$ Throughout the In Amenas siege, the Norwegian government (including the Prime Minister's Office) thus shared sensitive information and established daily communication with Statoil's top management. This is an example of how implementing the DoC instigated new public-private practices in addition to established government routines, such as initiating liaisons with and facilitating crisis response for Statoil, setting up a crisis team and sending an emergency unit to Algeria.

Like in Algeria, the crucial and reoccurring questions of 'who owns the crisis' and who has the responsibility for acting on the DoC were present during the Fukushima crisis. Whenever Norway has a diplomatic presence in an area affected by crisis, the Norwegian embassy provides information that largely shapes decision-making. Since the scope of the Fukushima crisis was unprecedented, many governments, including the Norwegian, upgraded their embassy's role and response on site. Norway's Tokyo Embassy, which played a prominent role in implementing the DoC towards Norwegian citizens in Japan, is mid-sized with around 30 employees, seven of which are Norwegian diplomats. The embassy's crisis-response capacity was enhanced by additional MFA staff, who came from Oslo and nearby Norwegian embassies (from the emergency roster). In the event of crisis abroad, an embassy is to contact the Oslo-based Response Centre. ${ }^{73}$ When contacted about the triple disaster, the Response Centre established a response team consisting of eleven generalists who consulted specialized authorities, including the police and health care professionals. ${ }^{74}$ Despite the Norwegian Embassy's and response team's input,

71 MFA, Terrorangrepet på gassproduksjonsanlegget $i$ In Amenas [The Terrorist Attack on the Gas Production Plant at In Amenas].

72 Interview 4; Engebretsen-Skaret, 'Utvikling i bruken av spesialstyrkene i internasjonale operasjoner [Development in the Use of Special Forces in International Operations].

73 Interview 1.

74 Interview 4. 
the ultimate decision-maker was the Norwegian MFA in Oslo, as is usually the case.

The DoC on the part of Norwegian embassies in the wake of a crisis is first to confirm the safety of in-country diplomats, embassy employees and then other Norwegian citizens. The main Norwegian concern during the Fukushima crisis was the nuclear radiation risk. ${ }^{75}$ In addition to the travel registry, embassies often also have a 'Norwegian list' of contacts, which officers use in times of crisis when attempting to make individual contact with citizens by telephone or e-mail. A 'guestimate' of how many Norwegians are in Japan at any given time is about 500 citizens. Despite having a list of in-country Norwegian citizens, contact with and communication by telephone with the victims was often cut off, precisely because of the crisis. In times of major crisis, Norwegian embassies advise listening to the local news, with the caveat that language can be a significant barrier here. While Japanese-language competence is sufficient at the Norwegian Embassy in Japan, accessing information, for instance about Japanese health care, was a challenge in this particular crisis. ${ }^{76}$ One informant also described most people as being 'spooked' by Fukushima, since they were receiving conflicting reports and had a hard time assessing risk, especially in the immediate wake of the disaster when individuals provided the initial communications. ${ }^{77}$

\section{Sobering Up? Investigations and Lessons Learned}

It often takes a crisis to generate change in response and security procedures. As interviewees put it, there is 'nothing like a crisis to expose holes in plans and things that fall between the cracks' and 'as with wars, it is the same with disasters: preparation is based on the last disaster. ${ }^{78}$ Learning from the In Amenas and Fukushima experiences instigated revised response mechanisms in Norway, with a view to improving implementation of the $\mathrm{DoC}$ at both government and company levels.

The Norwegian MFA's investigation of the attack at In Amenas pointed to unclear chains of responsibility and roles, ineffective use of resources, information gaps across ministries and agencies, and inadequate planning for

\footnotetext{
75 Interview 4.

76 Interview 1.

77 Interview 2.

78 Interview 2; Interview 1; and Interview 4.
} 
multidimensional crises as critical. ${ }^{79}$ The Response Centre, which was central in the ministerial process of establishing best public and private $\mathrm{DoC}$ practices, emphasized better sharing of classified and unclassified information, more liaising with private actors, and hosting annual dialogue meetings with organizations responsible for security abroad. Specific to the In Amenas incident was the unprecedented practice of having a regular, direct dialogue between Statoil and the Norwegian government throughout the crisis, which facilitated coordination and information-sharing, especially during the siege.

Statoil appointed an investigation commission of six members, chaired by a former head of the Norwegian Intelligence Service (Politiets Sikkerhetstjeneste, PST) and member of the ' 22 July Commission' ${ }^{80}$ Yet even before the report was finalized, Statoil initiated new routines, structures and a 'culture' of concern to ensure integration of a new understanding of security and safety across the company. It established a Security and Emergency Response International (ERI) unit at the senior management level and initiated measures to improve the training of on-site personnel and to strengthen dialogue with host and Norwegian authorities. ${ }^{81}$ A new model for Algeria entailed a different security organization, more personnel and a broader mandate, and one person was assigned primary responsibility for security on site. ${ }^{82}$ Furthermore, a wide network of employees with responsibility for security in petroleum companies regularly meet and convene meetings with Norwegian authorities, embassies, partners and companies within the security business.

As noted above, the 'private' DoC entails that a company should prepare, train and equip its employees and, when crises or incidents occur, have instruments at hand to minimize their impact and scale. While states' embassies and military compounds occasionally have been attacked (instances include the US Embassies in Kenya in 1998 and Libya in 2012, the Norwegian Embassy in Syria in 2006, and the military base in Afghanistan in 2006 and 2012), largescale, violent attacks on energy infrastructure have been rare. ${ }^{83}$ Regarding the specific DoC performed by Statoil, while recognizing already at the time of entry that the activity was in a high-risk environment, no Statoil initiatives

79 MFA, Terrorangrepet på gassproduksjonsanlegget $i$ In Amenas [The Terrorist Attack on the Gas Production Plant at In Amenas], p. 4.

8o Interview 5. Appointing an external chair to the Statoil investigation and publishing the report were linked to Norway's 'openness culture'. See Statoil, The In Amenas Attack, p. 1; and Interview 5 .

81 According to Helga Nes, Executive Vice-President at Statoil; Statoil, The In Amenas Attack.

82 Interview 5 .

83 Algerian Gas Challenges After the Attack on In Amenas (Barcelona: СIDOB, 2013). 
were made 'to independently quality assure or verify security in the In Amenas joint venture. ${ }^{84}$ Interestingly, Statoil had been in a process of evaluating the 'culture and consciousness' about safety and security in the company prior to the attack, more than doubling security personnel in the Development and Production International (DPI) unit since 2012. ${ }^{85}$ However, Statoil's investigation report (2013) criticized the heavy reliance on the Algerian Army for protection, its recruitment policies and routines, and the Sonatrach internal security department. One interviewee confirmed this view: 'Statoil's security set-up onsite at In Amenas looks different today, but Statoil did nothing wrong prior to the incident'. 86

Increased presence also increases risk, according to the company: 'Statoil establishes itself in ever more new places in the world, which increases various non-technical risk environments' ${ }^{87}$ Regarding lessons learned about how to implement the DoC, the investigation report stressed that overall responsibility for the tragedy nevertheless lies with the terrorists. Apparently, the attack could not have been foreseen and no preventive measures would have been able to withstand it:

Even if governments and companies do everything in their power to protect people and assets, they will still face the threat of terrorism. This is true regardless of where enterprises are engaged, whether in Algeria or in Norway. How serious the threat is, and how to best counter it, will vary. ${ }^{88}$

In sum, the In Amenas crisis showed that the ability of employers and states to act on the DoC in risk-prone areas depends on measures taken by the companies themselves, host governments and foreign governments, as well as the geopolitical context. Some experts claim that Statoil should have been aware of the heightened risk in Algeria, indicating that economic interests had trumped security assessments. ${ }^{89}$

Improvements regarding the $\mathrm{DoC}$ for citizens and foreign populations after the 'triple disaster' in Japan in 2011 generally focused on contingency planning,

\footnotetext{
84 Statoil, The In Amenas Attack, p. 5.

85 Statoil, 'Styrket sikkerhetsbevissthet' [Strengthened Safety Consciousness] (Oslo: Statoil, 21 June 2013).

86 Interview 5 .

87 Statoil, 'Styrket sikkerhetsbevissthet' [Strengthened Safety Consciousness]. At the time of the attack, Statoil was engaged in 36 countries.

88 Statoil, The In Amenas Attack, p. 1.

89 See online at https://www.nrk.no/ytring/ett-ar-etter-in-amenas-1.11473782.
} 
individual awareness, joining forces with allies in relief efforts at national and international levels, detailed emergency-response schemes, and new government bodies, such as the Nuclear Regulation Authority (NRA) in 2012. However, when seventeen Japanese citizens were taken hostage and ten were killed in the In Amenas terrorist attack in January 2013, it revealed that the Japanese government still suffered major information-gathering and response handicaps. ${ }^{90}$ As a direct response to the In Amenas crisis, Japan established the National Security Council (NSC) in 2013 to deliberate on important matters relating to national and citizen security.

Japanese authorities also took measures to internalize and institutionalize their DoC for foreign citizens by strengthening the response by the National Police Agency (NPA), the Tokyo Fire Department and the Tokyo Metropolitan Government (TMG). In 2015, the TMG issued an English-language version of the 300+ page manual on disaster preparedness for foreign residents, which shares information, quizzes and even cartoons on how best to prepare oneself for and act during and after crisis. ${ }^{91}$ Most notably, the TMG has held annual disaster preparedness programmes in English for foreign residents in Tokyo, where around 200 foreign residents experience an earthquake simulator, are trained in rescue activities and participate in role-playing telephone conversation exercises with Japanese staff. ${ }^{92}$ Foreign diplomats, including Norwegian, have participated in these exercises, and the Norwegian Embassy in Tokyo has regular bilateral protocol meetings with the NPA.

Establishing the division of labour within the Norwegian government during crisis response was also a challenge during the Fukushima crisis. Concerning the DoC for affected Norwegians, the Norwegian government followed established practices, but also stretched them. Citizens were contacted, provided with updated information based on expert opinions and host country reporting, including on the radiation risk, and on-the-ground and air transport out of the crisis area was also facilitated. The Norwegian Embassy evaluated its own handling of the triple disaster as being done fairly well, suggesting that it would respond similarly to a crisis of comparable size and scope. ${ }^{93}$

9o Masayuki Hiromi, 'Act of Partial Revision of the Establishment of the National Security Council of Japan and a Related Act', Waseda Bulletin of Comparative Law, vol. 33 (2014), pp. 133-137 at p. 134.

91 Disaster Preparedness in Tokyo (Tokyo: Tokyo Metropolitan Government, 2015).

92 See online at http://www.metro.tokyo.jp/ENGLISH/TOPICS/2015/151209.htm.

93 Interview 1. 


\section{Conclusion}

This article has analysed the state's duty to care for citizens who fall victim to unforeseen catastrophic or violent events abroad. The concept of the duty of care (DoC) highlights the challenges, dynamics and relations involved in diplomatic practice that is aimed at protecting citizens outside of state borders, and where traditional security concepts have had little to offer. Implementing this duty has become increasingly demanding for governments and companies, because of global work, travel and residence patterns, as well as more insecure environments, as demonstrated by the two crises discussed in this article.

In Norway, which was central for this article's illustrations of the DoC, citizens abroad are in principle well-protected, although both crises revealed critical gaps in relief assistance and coordination. While the DoC concerns the state-citizen relationship, during crises it also involves other states, as well as private actors (such as companies). The crises analysed here revealed several challenges regarding cooperation between host and foreign governments, including sensitivity related to the provision of security on the ground and accepting foreign assistance. During both the In Amenas and Fukushima crises, Norwegian authorities offered assistance to the host government that were never taken up.

Regarding crisis ownership, Statoil's considerable crisis organization toned down that question during the In Amenas siege. At the government level, the Norwegian MFA was 'lead ministry' in crisis response, although the Prime Minister's Office was also heavily involved. Concerning Fukushima, although the host government owned the crisis, Norway upgraded the Norwegian Embassy's response because of the unprecedented scope of the triple disaster and the stress that it placed on Japanese response and resources.

Finally, the crises at In Amenas and Fukushima triggered new ad-hoc but also longer-term diplomatic practices at the government (embassy, home and host country) and company levels, especially concerning liaising and information-sharing with stakeholders, to improve adherence to the DoC. Here, practical skills and measures beyond traditional diplomacy and institutionalized crisis mechanisms were warranted.

Based on this analysis, we cannot generalize about the understanding and implementation of the DoC beyond the In Amenas and Fukushima crises, since there are likely to be considerable national and company variations, and future crises might look different from those in the past. Yet our findings both welcome and require further analysis of how states' foreign policy and 
semi- and private international business engagements invoke the DoC for citizens abroad.

Nina Græger is a Senior Research Fellow at the Norwegian Institute of International Affairs (NUPI). She has published extensively on European security, defence cooperation, Norwegian foreign policy, and inter-organizational relations. Recent publications include 'Grasping the Everyday and Extraordinary in EU-NATO Relations: The Added Value of Practice Approaches'(European Security, vol. 26, no. 3, 2017) and Norwegian Defence Policy: Territorial Defence and International Operations, 19902015 (Oslo: Scandinavian Academic Press, 2016, in Norwegian).

Wrenn Yennie Lindgren is a Research Fellow at the Norwegian Institute of International Affairs (NUPI), an Associate Fellow at the Swedish Institute of International Affairs (UI) and a Ph.D. candidate in International Relations at Stockholm University. She specializes in the politics and foreign policy of Japan, international relations in East Asia, East Asian states' interests in the Arctic, and traditional and non-traditional security issues in the AsiaPacific region. She has recently published in Asian Politics \& Policy, and coedited the volume China and Nordic Diplomacy (London: Routledge, 2018).

\section{Appendix 1}

Interviews

\begin{tabular}{lll}
\hline Interview\# & Position \& affiliation & Date \\
\hline Interview 1 & Diplomat, Norwegian Embassy Tokyo & Tokyo, June 2015 \\
Interview 2 & Researcher, University Sector & Tokyo, June 2015 \\
Interview 3 & Researcher, University Sector & Tokyo, June 2015 \\
Interview 4 & Advisors, Norwegian MFA Foreign & Oslo, May 2016 \\
& Service Response Centre & \\
Interview 5 & Statoil employees, Oslo & Oslo, May 2016 \\
Interview 6 & Researcher, Institute Sector & Tokyo, June 2015 \\
Interview 7 & Consultant, International sos & Oslo, June 2016
\end{tabular}

